\title{
Corrosion Properties and Microstructure of a Broad Range of Ce Additions on Mg-Zn Alloy
}

\author{
Kyung Chul Park ${ }^{1}$, Byeong Ho Kim ${ }^{1}$, Hisamichi Kimura ${ }^{2}$, Yong Ho Park ${ }^{1, *}$ and Ik Min Park ${ }^{1, *}$ \\ ${ }^{1}$ Department of Material Science and Engineering, Pusan National University, \\ San 30 Jangjeon-dong, Geumjeong-gu, Busan 609-735, Korea \\ ${ }^{2}$ Institute for Materials Research, Tohoku University, Sendai 980-8577, Japan
}

To launch a new class of $\mathrm{Mg}$ alloys based on the $\mathrm{Mg}-\mathrm{Zn}$ system, the effect of microstructural evolution on the corrosion properties in $\mathrm{Mg}-\mathrm{Ce}-\mathrm{Zn}$ system has been investigated. The alloys were fabricated by using a vacuum induction melting method under an argon atmosphere. Potentiodynamic polarization and hydrogen evolution test were carried out in $3.5 \% \mathrm{NaCl}$ solution of $\mathrm{pH} 7.2$ at room temperature to evaluate the corrosion properties of $\mathrm{Mg}-\mathrm{Ce}-\mathrm{Zn}$ alloys. The main constituents in $\mathrm{Mg}_{99} \mathrm{Ce}_{0.5} \mathrm{Zn}_{0.5}, \mathrm{Mg}_{98} \mathrm{Ce}_{1.5} \mathrm{Zn}_{0.5}$ and $\mathrm{Mg}_{92} \mathrm{Ce}_{7.5} \mathrm{Zn}_{0.5}$ alloys are $\alpha$ - $\mathrm{Mg}_{3}$ and $\mathrm{Mg}_{12} \mathrm{Ce}$ phase. On the other hand, $\mathrm{Mg}_{41} \mathrm{Ce}_{5}$ and $\mathrm{Mg}_{3} \mathrm{Ce}$ phases are present in $\mathrm{Mg}_{88} \mathrm{Ce}_{11.5} \mathrm{Zn}_{0.5}$ and $\mathrm{Mg}_{86} \mathrm{Ce}_{13.5} \mathrm{Zn}_{0.5}$. Although Ce additions on $\mathrm{Mg}$ alloy could tend to ennoble the corrosion potential, the corrosion rate was increased with excessive Ce additions. [doi:10.2320/matertrans.F-M2011833]

(Received November 29, 2010; Accepted May 11, 2011; Published December 28, 2011)

Keywords: magnesium-cerium-zinc alloys, corrosion, microstructure

\section{Introduction}

Because of their low density, high specific strength and stiffness, Mg alloys have become candidate materials for many applications in microelectronics and in the automobile and aerospace industries. ${ }^{1-3)}$ The $\mathrm{Mg}-\mathrm{Al}$ system, such as AZ91D and AM60B, has been the basis of the most widely used for Mg casting alloys. Although they are widely used in automotive industry, their applications are limited to the parts operated at temperature below $120^{\circ} \mathrm{C}$ because they show poor creep resistance and large decrease in strength at elevated temperature due to the thermal instability of microstructure. Moreover, $\mathrm{Mg}$ is also well known as a very active metal and its alloys have a low corrosion resistance, resulting in restricted application of $\mathrm{Mg}$ alloys to exposure environment. Therefore, in order to be extensively used in the automobile industry it is very important to improve the elevated temperature properties and corrosion resistance of $\mathrm{Mg}$ alloys.

In order to enhance the corrosion resistance of $\mathrm{Mg}$ alloys, many intensive and extensive fundamental investigations have been carried out during the past decade. ${ }^{4-8)}$ Most of studies have focused on role of alloying elements on corrosion properties of $\mathrm{Mg}$ alloys. Especially, it was reported that the addition of rare earth elements (RE) to $\mathrm{Mg}$ alloys has favorable effects on the various properties. ${ }^{9-11)}$ Therefore, the mechanical and corrosion properties of $\mathrm{Mg}$ alloys with $\mathrm{RE}$ elements, i.e. $\mathrm{Ce}$, $\mathrm{La}$ and $\mathrm{Nd}$, have become an important issue. However, the effect of RE additions on these properties of $\mathrm{Mg}$ alloys is not completely understood.

Typically RE is extracted as misch-metals of various compositions, most commonly $\mathrm{Ce}$, followed by $\mathrm{La}$, with smaller amounts of $\mathrm{Nd}$ and $\mathrm{Pr}$, etc. In the $\mathrm{Mg}-\mathrm{RE}$ alloys there are many different phases that may form, which are common to each of the rare earths considered in this paper, such as the $\mathrm{Mg}_{12} \mathrm{RE}, \mathrm{Mg}_{3} \mathrm{RE}$ or $\mathrm{Mg}_{2} \mathrm{RE}$ phases. According to a $\mathrm{Mg}-\mathrm{Ce}$

${ }^{*}$ Corresponding authors, E-mail: yhpark@pusan.ac.kr and impark@ pusan.ac.kr binary phase diagram, ${ }^{12)}$ the maximum solubility of $\mathrm{Ce}$ in an $\alpha-\mathrm{Mg}$ matrix is about 0.1 at $\%$ at $590^{\circ} \mathrm{C}$ and $\mathrm{Mg}_{12} \mathrm{Ce}$, $\mathrm{Mg}_{41} \mathrm{Ce}_{5}, \mathrm{Mg}_{3} \mathrm{Ce}, \mathrm{Mg}_{2} \mathrm{Ce}$ and $\mathrm{MgCe}$ phases were formed with up to about $7.7,10.9,25,33.3$ and 50 at\% Ce addition, respectively. Recently, Zhang et al. studied the stoichiometry of two intermetallic compounds, $\mathrm{Mg}_{12} \mathrm{Ce}$ and $\mathrm{Mg}_{41} \mathrm{Ce}_{5}$, on synthesized and annealed alloys. ${ }^{13}$ ) They suggested a new phase diagram which containing newly suggested intermetallic compounds such as $\mathrm{Mg}_{11} \mathrm{Ce}$ and $\mathrm{Mg}_{39} \mathrm{Ce}_{5}$, but it needs to be more detailed study. Although Stoichiometry study on the binary compounds in the $\mathrm{Mg}-\mathrm{Ce}$ system is sometimes tried, the effect of $\mathrm{Mg}-\mathrm{Ce}$ intermetallic compounds on corrosion properties of $\mathrm{Mg}$ alloys is still unclear. In the present work, a broad range of Ce additions (0.5-13.5 at\%) on $\mathrm{Mg}-\mathrm{Zn}$ alloy has been investigated for evaluating their corrosion behavior. The aims of this study identify of the phases and evaluate the electrochemical behavior of a broad range of $\mathrm{Mg}-\mathrm{Ce}-\mathrm{Zn}$ alloys.

\section{Experimental Procedure}

Pure Mg (99.8\%), pure $\mathrm{Zn} \mathrm{(99 \% )} \mathrm{and} \mathrm{Mg-22} \mathrm{mass \% Ce}$ master alloy were used in this study. The alloys were fabricated by using a vacuum induction melting method under an argon atmosphere. All materials investigated in the present study are listed in Table 1. Microstructural analysis was carried out using an optical microscope and scanning electron microscope (SEM; Hitachi S-4300) equipped with an energy dispersive X-ray spectrometer (EDS). And the phases were analyzed via X-ray diffraction (Rigaku, CN2301) using monochromatic $\mathrm{CuK} \alpha$ radiation in as-cast state.

Potentiodynamic polarization test was carried out to easily understand the effects of microstructure on the corrosion resistance of the $\mathrm{Mg}-\mathrm{Ce}-\mathrm{Zn}$ alloys. The test was conducted in $3.5 \% \mathrm{NaCl}$ solution of $\mathrm{pH} 7.2$ at $25^{\circ} \mathrm{C}$ by using an Electrochemical Interface Solartron SI 1287. Platinum gauze $(25 \mathrm{~mm} \times 25 \mathrm{~mm}, 60 \mathrm{mesh})$ was used as a counter electrode, and an $\mathrm{Ag} / \mathrm{AgCl}$ electrode (in saturated $\mathrm{KCl}$ ) was used as a reference electrode. Polishing was carried out on samples 
Table 1 Nominal compositions of $\mathrm{Mg}-\mathrm{Ce}-\mathrm{Zn}$ alloys (mol\%).

\begin{tabular}{crrrc}
\hline \multicolumn{1}{c}{ Alloys } & \multicolumn{1}{c}{$\mathrm{Ce}$} & $\mathrm{Zn}$ & $\mathrm{Mg}$ & Remarks \\
\hline $\mathrm{Mg}_{99} \mathrm{Ce}_{0.5} \mathrm{Zn}_{0.5}$ & 0.5 & 0.5 & Bal. & Hypoeutectic alloy \\
$\mathrm{Mg}_{98} \mathrm{Ce}_{1.5} \mathrm{Zn}_{0.5}$ & 1.5 & 0.5 & Bal. & Hypoeutectic alloy \\
$\mathrm{Mg}_{92} \mathrm{Ce}_{7.5} \mathrm{Zn}_{0.5}$ & 7.5 & 0.5 & Bal. & Hypereutectic alloy \\
$\mathrm{Mg}_{88} \mathrm{Ce}_{11.5} \mathrm{Zn}_{0.5}$ & 11.5 & 0.5 & Bal. & Intermetallic \\
$\mathrm{Mg}_{86} \mathrm{Ce}_{13.5} \mathrm{Zn}_{0.5}$ & 13.5 & 0.5 & Bal. & Intermetallic \\
\hline
\end{tabular}

with $\mathrm{SiC}$ paper up to 600 grits before starting measurements. The experiments were done at least three times and the solutions were neither deaerated nor stirred. During electrochemical corrosion tests, electrode potential was measured at a scan rate of $0.2 \mathrm{mV} / \mathrm{s}$ from $-0.3 \mathrm{~V}$ versus open circuit potential (OCP) to $-0.8 \mathrm{~V}$ versus reference. For the hydrogen evolution measurements, rectangular samples with a dimension of $25 \times 12 \times 10 \mathrm{~mm}$ were prepared. The samples were

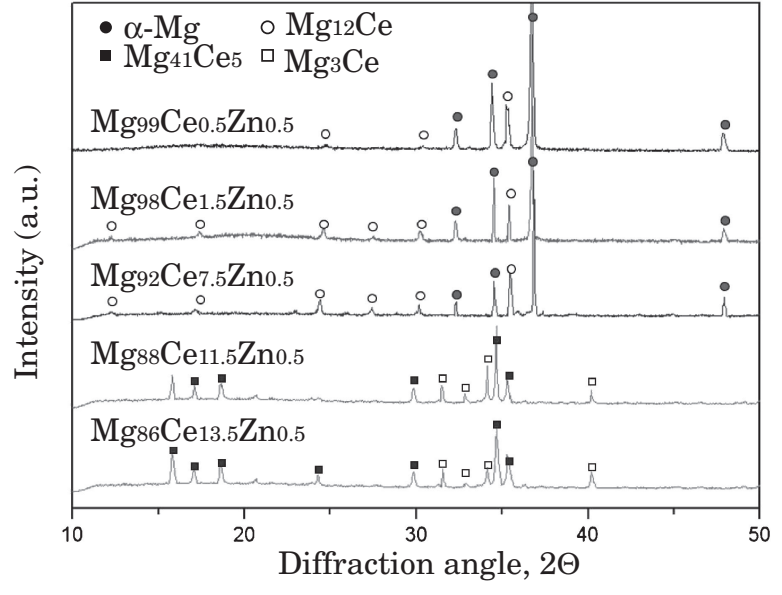

Fig. 1 X-ray diffraction patterns of various $\mathrm{Mg}-\mathrm{Ce}-\mathrm{Zn}$ alloys.

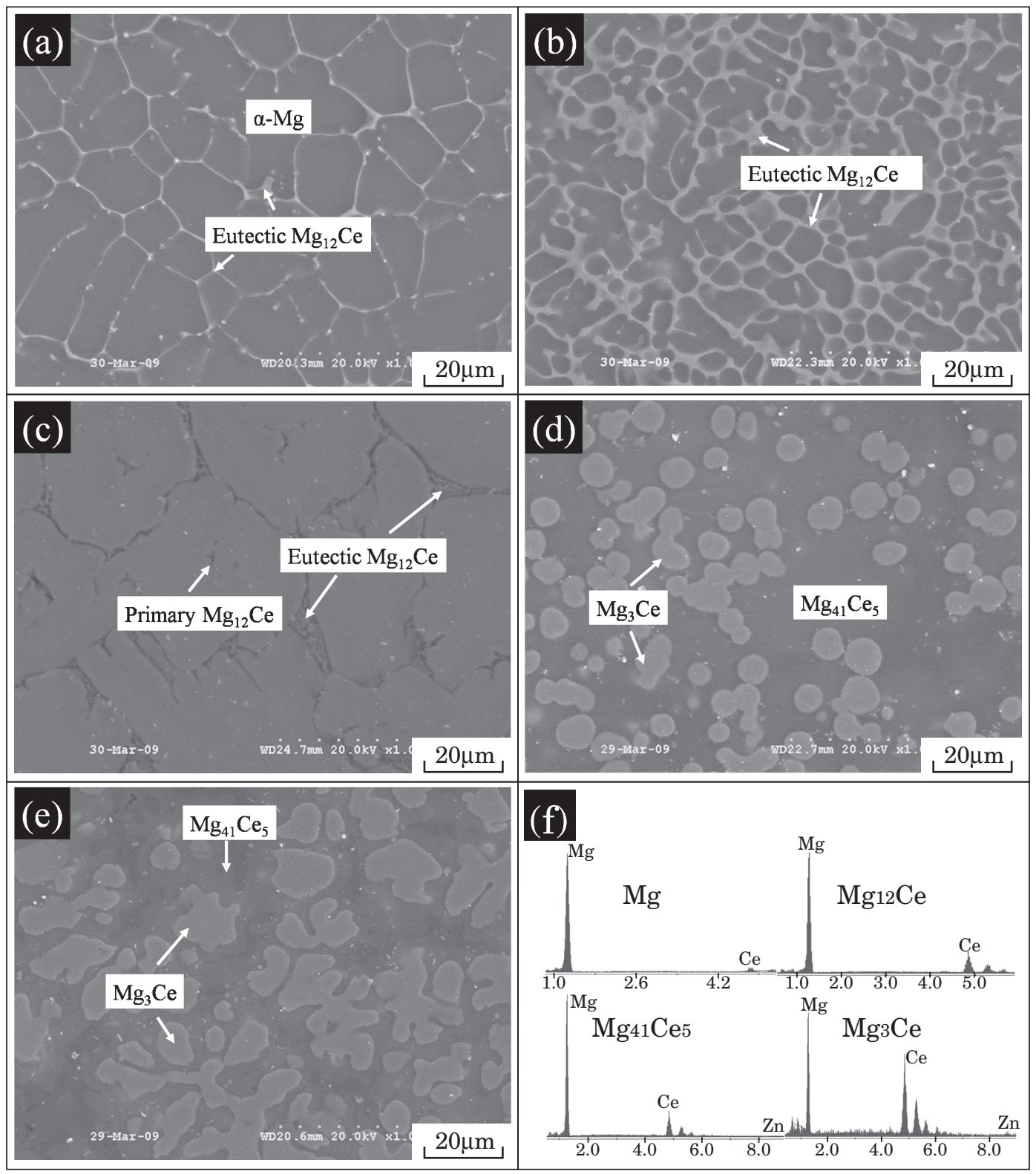

Fig. 2 SEM micrographs of the (a) $\mathrm{Mg}_{99} \mathrm{Ce}_{0.5} \mathrm{Zn}_{0.5}$, (b) $\mathrm{Mg}_{98} \mathrm{Ce}_{1.5} \mathrm{Zn}_{0.5}$, (c) $\mathrm{Mg}_{92} \mathrm{Ce}_{7.5} \mathrm{Zn}_{0.5}$, (d) $\mathrm{Mg}_{88} \mathrm{Ce}_{11.5} \mathrm{Zn}_{0.5}$ and (e) $\mathrm{Mg}_{86} \mathrm{Ce}_{13.5} \mathrm{Zn}_{0.5}$ alloys. The (f) shows the EDS spectrums of secondary phases in Figs. 2(a)-2(e). 


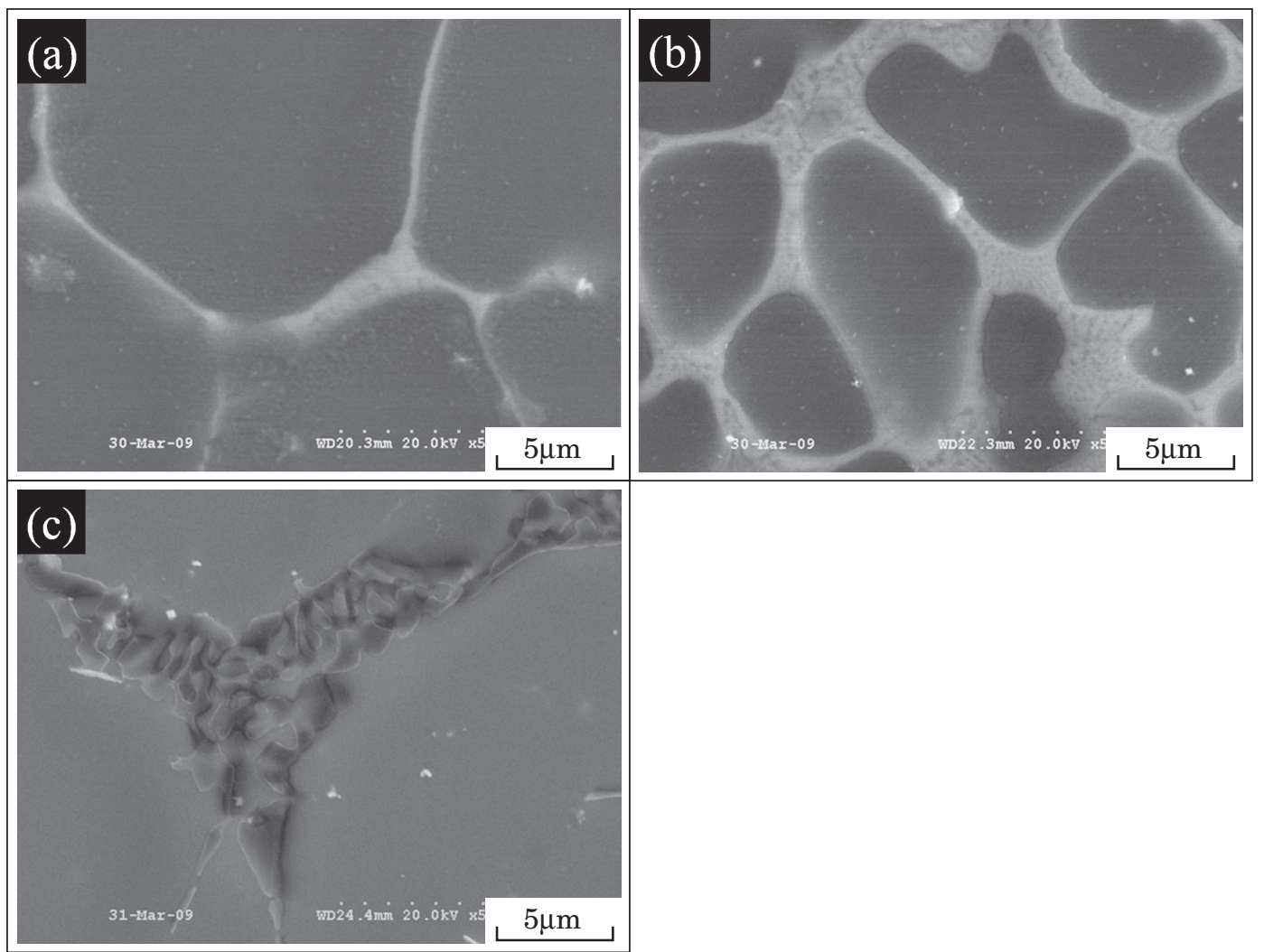

Fig. 3 SEM micrographs of eutectic structure of (a) $\mathrm{Mg}_{99} \mathrm{Ce}_{0.5} \mathrm{Zn}_{0.5}$, (b) $\mathrm{Mg}_{98} \mathrm{Ce}_{1.5} \mathrm{Zn}_{0.5}$ and (c) $\mathrm{Mg}_{92} \mathrm{Ce}_{7.5} \mathrm{Zn}_{0.5}$ alloys.

placed on a pyrex glass plate filling with $3.5 \% \mathrm{NaCl}$ solution (pH 7.2) and a calibrated hydrogen collection tube was set up over the corroding sample. The volume of evolved hydrogen was measured every $30 \mathrm{~min}$ during $72 \mathrm{~h}$ and the corrosion rate was calculated in $\mathrm{ml} \mathrm{cm}^{-2}$.

\section{Results and Discussion}

\subsection{Microstructure}

Figure 1 shows the optical microscopic images of the $\mathrm{Mg}_{99} \mathrm{Ce}_{0.5} \mathrm{Zn}_{0.5}, \mathrm{Mg}_{98} \mathrm{Ce}_{1.5} \mathrm{Zn}_{0.5}, \mathrm{Mg}_{92} \mathrm{Ce}_{7.5} \mathrm{Zn}_{0.5}, \mathrm{Mg}_{88} \mathrm{Ce}_{11.5^{-}}$ $\mathrm{Zn}_{0.5}$ and $\mathrm{Mg}_{86} \mathrm{Ce}_{13.5} \mathrm{Zn}_{0.5}$ alloys. As shown in hypoeutectic and hypereutectic alloys of Figs. 1(a)-1(c), these alloys exhibited a typical dendritic structure. With the increase of Ce contents, the dendritic structures became more obvious. On the other hand, the microstructure of $\mathrm{Mg}_{88} \mathrm{Ce}_{11.5} \mathrm{Zn}_{0.5}$ and $\mathrm{Mg}_{86} \mathrm{Ce}_{13.5} \mathrm{Zn}_{0.5}$ alloys in Figs. 1(d) and 1(e) shows absolutely different images comparing with hypo- and hypereutectic alloys.

Figure 2 shows the SEM images and EDS spectrum of secondary phases in $\mathrm{Mg}-\mathrm{Ce}-\mathrm{Zn}$ alloys. SEM/EDS results indicate that the main constituents in $\mathrm{Mg}_{99} \mathrm{Ce}_{0.5} \mathrm{Zn}_{0.5}$, $\mathrm{Mg}_{98} \mathrm{Ce}_{1.5} \mathrm{Zn}_{0.5}$ and $\mathrm{Mg}_{92} \mathrm{Ce}_{7.5} \mathrm{Zn}_{0.5}$ alloys are $\alpha-\mathrm{Mg}$ and $\mathrm{Mg}_{12} \mathrm{Ce}$ phase. On the other hand, $\mathrm{Mg}_{41} \mathrm{Ce}_{5}$ and $\mathrm{Mg}_{3} \mathrm{Ce}$ phases are present in $\mathrm{Mg}_{88} \mathrm{Ce}_{11.5} \mathrm{Zn}_{0.5}$ and $\mathrm{Mg}_{86} \mathrm{Ce}_{13.5} \mathrm{Zn}_{0.5}$; $\mathrm{Mg}_{41} \mathrm{Ce}_{5}$ seems to have formed from a peritectic reaction of $\mathrm{Mg}_{3} \mathrm{Ce}+\mathrm{L} \rightarrow \mathrm{Mg}_{41} \mathrm{Ce}_{5}$. On the other hand, neither $\mathrm{Ce}-\mathrm{Zn}$ intermetallic nor the ternary phases were detected. Figure 3 shows the comparison of eutectic structure of $\mathrm{Mg}_{99} \mathrm{Ce}_{0.5} \mathrm{Zn}_{0.5}$, $\mathrm{Mg}_{98} \mathrm{Ce}_{1.5} \mathrm{Zn}_{0.5}$ and $\mathrm{Mg}_{92} \mathrm{Ce}_{7.5} \mathrm{Zn}_{0.5}$ alloys. With increase of Ce additions, the size of eutectic phase was coarsened.

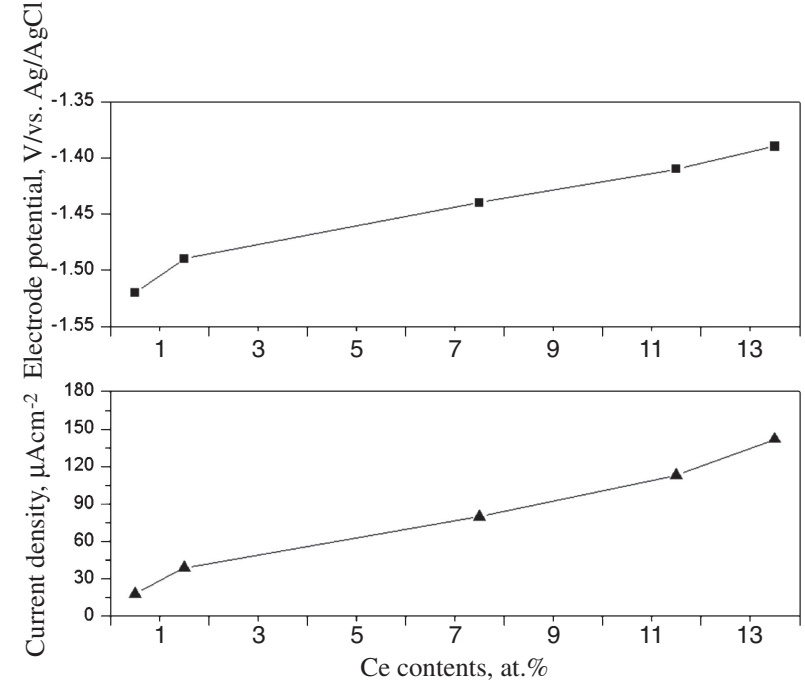

Fig. 4 Summary of potentiodynamic polarization test in $3.5 \% \mathrm{NaCl}$ solution. Values are given for corrosion potential $\left(E_{\text {corr }}\right)$ and corrosion rate $\left(I_{\text {corr }}\right)$.

\subsection{Corrosion properties}

The results obtained from the two types of corrosion tests of $\mathrm{Mg}-\mathrm{Ce}-\mathrm{Zn}$ alloys are presented in Figs. 4 and 5, with the former for the polarization test and the latter for the hydrogen evolution test.

Potentiodynamic polarization tests were carried out in triplicate and summarized in Fig. 4. From the Fig. 4, we see the values for the corrosion potential $\left(E_{\text {corr }}\right)$ and the corrosion rate (expressed in the form of corrosion current density, $I_{\text {corr }}$ ) 


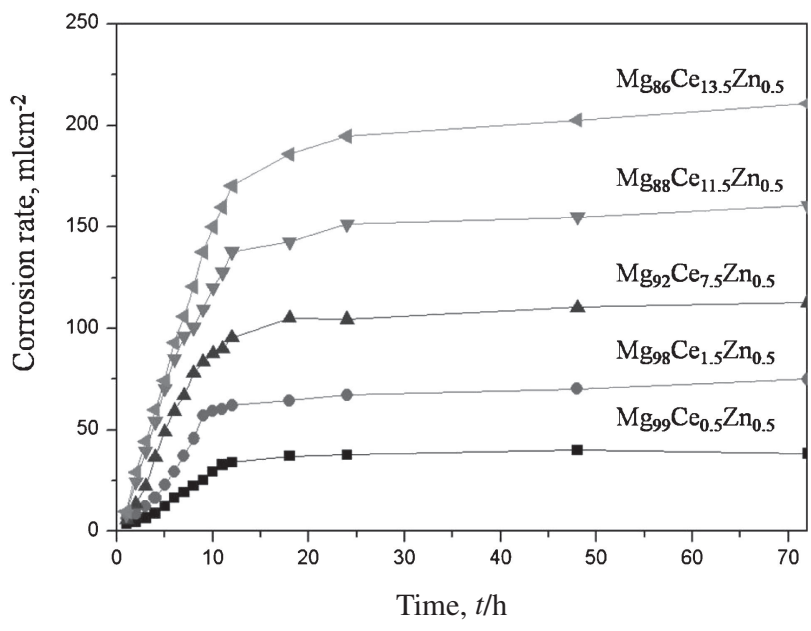

Fig. 5 Corrosion rates of $\mathrm{Mg}-\mathrm{Ce}-\mathrm{Zn}$ alloys as a function of immersion time. for the alloys tested in $3.5 \% \mathrm{NaCl}$ solution. The corrosion potential of $\mathrm{Mg}_{99} \mathrm{Ce}_{0.5} \mathrm{Zn}_{0.5}, \mathrm{Mg}_{98} \mathrm{Ce}_{1.5} \mathrm{Zn}_{0.5}, \mathrm{Mg}_{92} \mathrm{Ce}_{7.5} \mathrm{Zn}_{0.5}$, $\mathrm{Mg}_{88} \mathrm{Ce}_{11.5} \mathrm{Zn}_{0.5}$ and $\mathrm{Mg}_{86} \mathrm{Ce}_{13.5} \mathrm{Zn}_{0.5}$ alloys was -1.52 , $-1.49,-1.44,-1.40$ and -1.39 , respectively. Results indicated that increasing Ce alloying addition leads to an increase of the corrosion potential by an amount of up to 30$130 \mathrm{mV}$. This suggests that the addition of $\mathrm{Ce}$ tends to ennoble the $E_{\text {corr }}$ value of the $\mathrm{Mg}$ alloys. On the other hand, the value of $I_{\text {corr }}$ was also increased with increasing of $\mathrm{Ce}$ additions. It suggests that the value of $E_{\text {corr }}$ however-which may be of relevance should alloys be galvanically coupledis not indicative of corrosion rate. This is already confirmed in our previous study and very clear. And a similar phenomenon was also reported in the other study. ${ }^{14)}$

Normally, the addition of RE ( $\mathrm{La}, \mathrm{Ce}$ and $\mathrm{Nd}$ ) is believed to have a beneficial effect on the corrosion resistance of $\mathrm{Mg}$ alloys. Takenake et al. indicated that the small addition of $\mathrm{RE}$ has a beneficial effect on the corrosion properties but

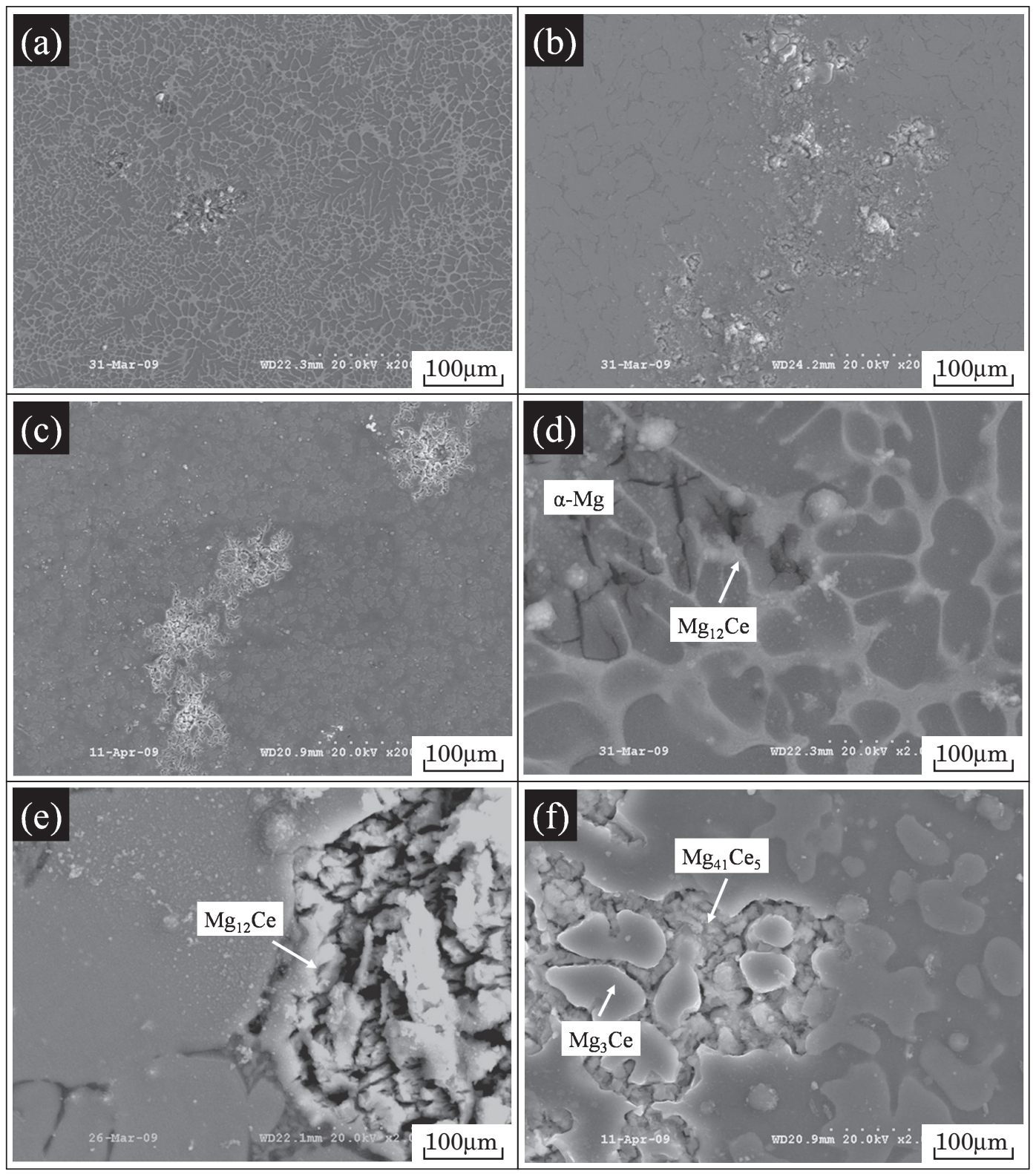

Fig. 6 SEM micrographs of corroded surface after 10 min in $3.5 \% \mathrm{NaCl}$ solution; (a) and (d) $\mathrm{Mg}_{98} \mathrm{Ce}_{1.5} \mathrm{Zn}_{0.5}$, (b) and (e) $\mathrm{Mg}_{92} \mathrm{Ce}_{7.5} \mathrm{Zn}_{0.5}$ and (c) and (f) $\mathrm{Mg}_{88} \mathrm{Ce}_{11.5} \mathrm{Zn}_{0.5}$ alloys. 
excessive RE addition deteriorates the corrosion resistance. ${ }^{11)}$ In this work, excessive $\mathrm{Ce}$ additions seem to be caused to increase in corrosion rates. Hence it is clear that the RE additions on $\mathrm{Mg}$ alloys does not always associate with an improvement in corrosion resistance.

Figure 5 illustrates corrosion rates of a broad range of the $\mathrm{Mg}-\mathrm{Ce}-\mathrm{Zn}$ alloys immersed in $3.5 \% \mathrm{NaCl}$ solution. The corrosion rates were increased with increasing of excessive $\mathrm{Ce}$ additions. And all of alloys show that the corrosion rate was steadily increased with increase of immersion time. In order to clear the influence of microstructural evolution on corrosion properties of $\mathrm{Mg}-\mathrm{Ce}-\mathrm{Zn}$ alloys, the SEM images of initial corrosion stage were described in Fig. 6. The initial corrosion stage of the samples is shown in Fig. 6. From the Figs. 6(a)-6(c), several regions with severe corrosion were observed due to the galvanic effect. Indeed, it is known that localized and galvanic corrosion is the most common form of corrosion for $\mathrm{Mg}$ alloys in chloride-containing solutions. The $\mathrm{Mg}-\mathrm{Ce}-\mathrm{Zn}$ alloys were also predominated over localized and galvanic corrosion.

In magnified images in Figs. 6(d)-6(f), the corrosion was initiated at interface of $\alpha-\mathrm{Mg} / \mathrm{Mg}_{12} \mathrm{Ce}$ and $\mathrm{Mg}_{41} \mathrm{Ce}_{5} / \mathrm{Mg}_{3} \mathrm{Ce}$ due to galvanic effect. It is reported that the corrosion potential of $\alpha-\mathrm{Mg}$ and $\mathrm{Mg}_{12} \mathrm{Ce}$ phase was known as -1.65 and $-1.5 \mathrm{~V}_{\mathrm{SCE}}$, respectively. ${ }^{14)}$ But that of other phases, $\mathrm{Mg}_{41} \mathrm{Ce}_{5}$ and $\mathrm{Mg}_{3} \mathrm{Ce}$, are still unclear. The initial corrosion was preferentially occurred at $\alpha-\mathrm{Mg}$ [in Fig. 6(d)] and $\mathrm{Mg}_{3} \mathrm{Ce}$ [in Fig. 6(f)]. It is indicated that the $\mathrm{Mg}_{12} \mathrm{Ce}$ phase has a higher galvanic potential than $\alpha-\mathrm{Mg}$ and $\mathrm{Mg}_{41} \mathrm{Ce}_{5}$ phase has a higher galvanic potential than $\mathrm{Mg}_{3} \mathrm{Ce}$. From these results, it is postulated that the corrosion potential of $\mathrm{Mg}-\mathrm{Ce}$ intermetallic compounds is increased with increasing of $\mathrm{Ce}$ additions.

\section{Conclusions}

In the present study, we have investigated the relationship between microstructural evolution and corrosion properties in $\mathrm{Mg}-\mathrm{Ce}-\mathrm{Zn}$ alloys. Major conclusions can be summarized as follows.

(1) The $\mathrm{Mg}_{99} \mathrm{Ce}_{0.5} \mathrm{Zn}_{0.5}, \mathrm{Mg}_{98} \mathrm{Ce}_{1.5} \mathrm{Zn}_{0.5}$, and $\mathrm{Mg}_{92} \mathrm{Ce}_{7.5^{-}}$ $\mathrm{Zn}_{0.5}$ alloys mainly consisted of $\alpha-\mathrm{Mg}$ and $\mathrm{Mg}_{12} \mathrm{Ce}$ phases. With the increase of Ce contents, the volume fraction of $\mathrm{Mg}_{12} \mathrm{Ce}$ phase was increased. On the other hand, $\mathrm{Mg}_{88} \mathrm{Ce}_{11.5} \mathrm{Zn}_{0.5}$ and $\mathrm{Mg}_{86} \mathrm{Ce}_{13.5} \mathrm{Zn}_{0.5}$ alloys composed of $\mathrm{Mg}_{41} \mathrm{Ce}_{5}$ and $\mathrm{Mg}_{3} \mathrm{Ce}$ phases.

(2) Ce additions lead to an increase of the corrosion potential of $\mathrm{Mg}$ alloy. But the excessive $\mathrm{Ce}$ additions lead to increase of corrosion rate.

(3) The main corrosion mechanism was confirmed as localized and galvanic corrosion.

\section{Acknowledgements}

This research was supported by a grant from the Fundamental R\&D Program for Core Technology of Materials, from the Ministry of Knowledge Economy, Republic of Korea and a grant-in-aid for support from the Tohoku University Global COE program.

\section{REFERENCES}

1) B. H. Kim, H. Kimura, Y. H. Park and I. M. Park: Mater. Trans. 51 (2010) 1346-1349.

2) B. H. Kim, S. W. Lee, Y. H. Park and I. M. Park: J. Alloy. Compd. 493 (2010) 502-506.

3) K. C. Park, B. H. Kim, Y. H. Park and I. M. Park: Trans. Nonferrous Met. Soc. China 20 (2010) 1240-1243.

4) G. Song, A. L. Bowles and D. H. St. John: Mater. Sci. Eng. A 366 (2004) 74-86.

5) G. Song: Adv. Eng. Mater. 7 (2005) 563-586.

6) K. C. Park, B. H. Kim, H. Kimura, Y. H. Park and I. M. Park: Mater. Trans. 51 (2010) 472-476.

7) G. Ballerini, U. Bardi, R. Bignucolo and G. Ceraolo: Corros. Sci. 47 (2005) 2173-2184.

8) S. Mathieu, C. Rapin, J. Steinmetz and P. Steinmetz: Corros. Sci. 45 (2003) 2741-2755.

9) F. Rosalbino, E. Angelini, S. D. Negri, A. Saccone and S. Delfino: Intermetallic 14 (2006) 1487-1492.

10) X. W. Guo, J. W. Chang, S. M. He, W. J. Ding and X. S. Wang: Electrochim. Acta 52 (2007) 2570-2579.

11) T. Takenake, T. Ono, Y. J. Narazaki, Y. Naka and M. Kawakami: Electrochim. Acta 53 (2007) 117-121.

12) T. B. Massalski: Binary alloy phase diagrams, (ASM International, Ohio, 1990).

13) X. Zhang, D. Kevorkov and M. Pekguleryuz: J. Alloy. Compd. 475 (2009) 361-367.

14) N. Birbilis, M. A. Easton, A. D. Sudholz, S. M. Zhu and M. A. Gibson: Corros. Sci. 51 (2009) 683-689. 